\title{
Burden of HIV/AIDS infection before and during the civil war in Somalia
}

\author{
B.H. Ahmed, ${ }^{7}$ M.R. Giovagnoli, ${ }^{1}$ H. Mahad ${ }^{2}$ and G.G. Tarsitani ${ }^{1}$
}

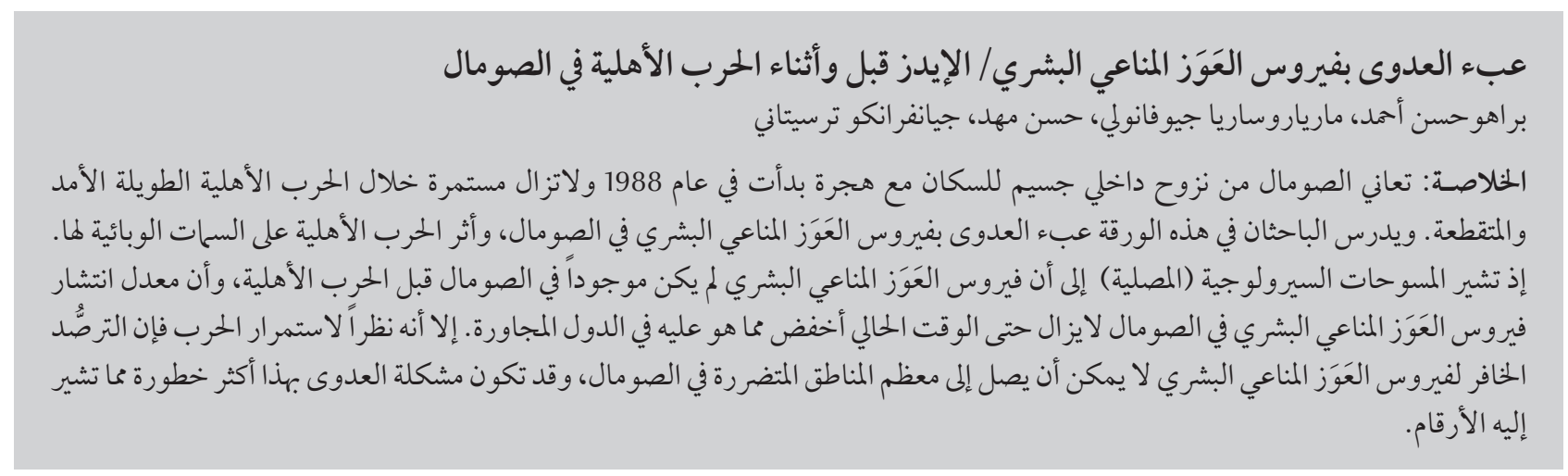

ABSTRACT Somalia has suffered a massive internal population displacement and exodus that began in 1988 and is still ongoing during the prolonged and intermittent civil war. This review looks at the burden of HIV infection in Somali and the impact of civil war on its epidemiology. Serosurveys have indicated that HIV was not present in Somalia before the civil war and to date Somalia has had an HIV prevalence markedly below that of its neighbours. However, due to the ongoing war HIV sentinel surveillance cannot reach most of the affected areas in Somalia and the current HIV infection problem may be greater than the figures indicate.

\section{Charge de l'infection par le VIH/sida avant et pendant la guerre civile en Somalie}

RÉSUMÉ Depuis 1988, la Somalie est confrontée à un déplacement massif de population à l'intérieur du pays et à un exode qui perdurent au cours de la guerre civile épisodique auquelle elle est confrontée de longue date. La présente analyse étudie la charge de l'infection par le VIH en Somalie et l'impact de la guerre civile sur son épidémiologie. Des enquêtes sérologiques ont révélé que le VIH n'était pas présent en Somalie avant la guerre civile et qu'à ce jour, la prévalence du VIH en Somalie était nettement inférieure à celle des pays voisins. Toutefois, en raison de la guerre qui sévit actuellement, la surveillance sentinelle du VIH ne peut accéder à la plupart des zones touchées en Somalie et le problème actuel relatif à l'infection au VIH pourrait être plus important que ce que les chiffres laissent entendre. 


\section{Introduction}

Somalia, situated on the Horn of Africa, has suffered a massive internal population displacement and exodus that began in 1988 with the rebellion in the north of the country, causing refugees to flee to camps in Ethiopia and Kenya. Other refugees from the north were resettled in Mogadishu, the capitol of Somalia, located on the central-southern coast. In 1991, armed militia overthrew the Somali central government. The population shift has continued during the ensuing prolonged and intermittent civil war. The conflict was still ongoing as of March 2008 [1]. In this review we look at the burden of human immunodeficiency virus (HIV) infection in Somalia and the impact of civil war on its epidemiology.

\section{Methods}

To review the HIV epidemic before and during the civil war in Somalia, the data in this article were identified from a search using the PubMed search engine and the keywords "East Africa", "Somalia" "HIV" and "AIDS". United Nations (UN) reports and articles published in international journals not indexed by PubMed were also included. The selection was based on original research articles and critical reviews by major investigators. Key issues related to the HIV epidemic in Somalia from early studies collected in different sites were summarized, including a serosurveillance survey conducted by the World Health Organization (WHO) in 3 different zones: South-Central Somalia, Puntland and Somaliland.

\section{Results}

Before the civil war, some early HIV/ AIDS surveys were carried out in Somalia. Different population groups were tested, using serum collected from female sex workers, patients attending sexually transmitted disease (STD) clinics and patients with tuberculosis in Mogadishu and 2 other southern cities. Between 1978 and January 1987, antibodies against HIV were not detected in any of these groups [2-5]. A seroepidemiological survey was conducted in 1989 Mogadishu, the urban capital, and the rural areas of Marko, Qoryoley and Kismayo [6]. There were 1269 study subjects, including 57 female sex workers, 79 patients attending STD clinics and 1133 others, including hospitalized patients, outpatients, people from rehabilitation camps, secondary-school pupils and immigrants from Ethiopia. The people tested were suffering from leprosy, tuberculosis and other infectious diseases. The results showed that none of them tested positive for HIV-1 and HIV-2.

Further studies were carried out in July and August 1985 and January 1986 on 471 serum samples, from 3 different groups of women aged 14-48 years, including pregnant women admitted to hospital and their newborn babies, women with higher education (physicians, nurses, university students and administrative staff) and sex workers. All were negative for HIV antibodies [7].

The first HIV-antibody positive sample in Somalia was found in 1987 among serum samples collected from 287 female sex workers in Mogadishu and reported first by Burans at the IVth International Conference on AIDS, Stockholm, in 1988 and later published by Ahmed et al. [8]. Another 4 cases of HIV were reported in Somalia in 1989. The numbers increased to 13 in $1991[6,9]$.

A follow-up study carried out in 1991 showed that the seroprevalence of HIV-1 antibodies was 3\% among female sex workers in Mogadishu, Merca and Kisimayo [10]. However, HIV infection was still rare in 1990 in Somalia, perhaps due to the low level of trade activity between Somalia and the rest of Africa [11]. By 2000, the figures reported for Somalia were still much lower than those reported from neighbouring countries $[12,13]$. In Kenya, Ethiopia and Djibouti the HIV epidemic reached double-digit rates of infection, as reported by the UN Joint Programme on HIV/AIDS in 2000 $[14,15]$. According to a WHO HIV surveillance report in 2004 in 3 regional zones (South-Central Somalia, Puntland and Somaliland), out of a total of 4732 people tested, 44 were positive for HIV (0.9\%). A follow-up report in 2007 indicated that the prevalence of HIV had increased to $2.2 \%$ in Bosaso, and 2.7\% in Berbera [16]. Based on the 2005 WHO estimate of the HIV status of Somalis, there were 40000 Somali adults living with HIV infection and 4200 new infections. The estimated death toll due to AIDS was 970 [17].

\section{Discussion}

Serosurveys have indicated that HIV was not present in Somalia before the civil war started. Other studies carried out during the war indicated that HIV was present at a low rate, although the prevalence has subsequently risen steadily to reach a maximum of $2.7 \%$, the latest figure recorded in the north of the country in 2007 [16]. The results of other studies emphasize that conflict is a risk factor for HIV transmission $[1,16,18]$. Somalia's population, still sporadically at war, is vulnerable to further exposure to HIV infection. Factors such as promiscuity, polygamy, high incidence of STD, malnutrition, poverty and the continued presence of some traditional practices such as the use of nonsterile tools for minor surgery are high risk for HIV transmission. Longstanding conflict and forced displacement can change the behaviour of a society and increase the risk of HIV [17]. Surveys conducted on the Somali population indicate that there is a lack of understanding and awareness of 
basic information about HIV, including mechanisms of prevention of transmission. Added to this are factors such as the widespread stigma attached to HIV infection; reluctance to disclose information to family and partners; gender inequalities that increase the vulnerability of women and girls; transfusion of unsafe blood; and the widespread use of qat which may be associated with high-risk behaviour [18].

Because of the ongoing war HIV sentinel surveillance cannot reach most of the affected areas in Somalia. The current HIV infection problem may be higher than the figures indicate. To date, Somalia has had an HIV infection rate markedly below that of its neighbours. This is most likely related to the cultural traditions and behavioural norms practised by Somalis, such as discouragement of extramarital sex and prostitution. This is in danger of change due the continued civil unrest in the country. Another practice which helped Somalis avoid the scourge of HIV may be male circumcision. Male circumcision has been suggested as a reason for the low prevalence of HIV in many communities which practise it in sub-Saharan Africa [19-21]. WHO has reported that male circumcision reduces the risk of HIV by approximately $60 \%$. The mechanism is thought to be that the HIV virus targets immune cells such as Langerhan cells, CD4+, T-cells and macrophages that are located in the mucosal side of the foreskin and that these are reduced in circumcised men. Furthermore, circumcision, by forming a thick layer of squamous epithelial cells, may act as a barrier to HIV uptake in the underlying target cells [22].

Special attention to HIV prevention and education, including more media information, is needed for the Somali population, who are still being dispersed by an ongoing war. Because of the lack of a central authority in the country, both surveillance programmes and possible interventions should be addressed in a decentralized way.

\section{References}

1. Gisselquist D. Impact of long-term civil disorders and wars on the trajectory of HIV epidemics in sub-Sahara Africa. SAHARA: Journal of Social Aspects of HIV/AIDS, 2004, 1(2):114-127.

2. Titti $\mathrm{F}$ et al. Lack of evidence of HTLV-II seropositivity in Somalia. AIDS Research, 1986, 2:161-162.

3. Jama $\mathrm{H}$ et al. Sexually transmitted viral infections in various population groups in Mogadishu, Somalia. Genitourinary Medicine, 1987, 63:29-32.

4. Jama $\mathrm{H}$ et al. A seroepidemiological survey of hepatitis B, human immunodeficiency, cytomegalovirus, and herpes simplex virus infections in a Somali village. Venerology, 1989, 2:100-105.

5. Burans JP et al. HIV infection surveillance in Mogadishu, Somalia. East African Medical Journal, 1990, 67(7):466-472.

6. Corwin AL et al. HIV-1 in Somalia, prevalence and knowledge of prostitutes. AIDS, 1991, 5:902-904.

7. Jama $\mathrm{H}$ et al. Sexually transmitted viral infections in various population groups in Mogadishu, Somalia. Genitourinary Medicine, 1987, 63:329-332.

8. Ahmed HJ et al. Syphilis and human immunodeficiency virus seroconversion during a six month follow-up of female prostitutes in Mogadishu, Somalia. International Journal of STD and AIDS, 1991, 2:119-123.

9. Statistics from the World Health Organization and the Centers for Disease Control. World Health Organization global statistics. AIDS, 1991, 5:911-915.

10. Oldfield EC, Rodier GR, Gray GC. The endemic infectious diseases of Somalia. Clinical Infectious Diseases, 1993, 16:S132-57.

11. Watts D et al. Low risk of sexual transmission of hepatitis C virus in Somalia. Transactions of the Royal Society of Tropical Medicine and Hygiene, 1994, 88:55-56.

12. Nur YA et al. Prevalence of serum antibodies against bloodborne and sexually transmitted agents in selected groups in Somalia. Epidemiology and Infection, 2000, 124(1):137-141.

13. Rodier GR et al. Trends of human immunodeficiency virus type 1 infection in female prostitutes and males diagnosed with a sexually transmitted disease in Djibouti, East Africa. American Journal of Tropical Medicine and Hygiene, 1993, 48:682-686.

14. Republic of Congo. Epidemiological fact sheets on HIV/AIDS and sexually transmitted infections-2000 update. Geneva, United Nations Joint Programme on HIV/AIDS, 2000.

15. Ethiopia. Epidemiological fact sheets on HIV/AIDS and sexually transmitted infections-2000 update. Geneva, United Nations Joint Programme on HIV/AIDS, 2000.

16. Country progress report 2008. Somaliland, Puntland and South Central Somalia. Narrative to supplement Country Response Information System report-February 2008. Reporting period:January 2006-December 2007. United Nations General Assembly Special Session on HIV/AIDS, 2008 (http://data.unaids.org/ pub/Report/2008/somalia_2008_country_progress_report_ en.pdf, accessed 18 March 2010).

17. AIDS epidemic update. Special report on HIV prevention. Geneva, United Nations Joint Programme on HIV/AIDS and World Health Organization, 2005 (UNAIDS/05.19E).

18. HIV epidemic and its response 2003-2005. Draft report on the UNGASS Declaration of Commitment. Geneva, United Nations Joint Programme on HIV/AIDS, 2005 (http://data.unaids.org/ pub/Report/2006/2006_country_progress_report_somalia_en.pdf, accessed 12 May 2010).

19. Weiss HA, Quigley MA, Hayes RJ. Male circumcision and risk of HIV infection in sub-Saharan Africa: a systematic review and meta-analysis. AIDS, 2000, 14(15):2361-2370.

20. Bailey RC et al. Male circumcision for HIV prevention in young men in Kisumu, Kenya: a randomised controlled trial. Lancet, 2007, 369:643-656.

21. Williams BG et al. The potential impact of male circumcision on HIV in Sub-Saharan Africa. PLoS Medicine, 2006, 3(7):e262 (doi:10.1371/journal.pmed.0030262).

22. Bailey RC, Egesah O, Rosenberg S. Male circumcision for HIV prevention: a prospective study of complications in clinical and traditional settings in Bungoma, Kenya. Bulletin of the World Health Organization, 2008, 86(9):669-677. 